\title{
Studies on in vitro regeneration competence of pseudobulb cultures in Changnienia amoena Chien
}

\author{
JIANG WeiMei ${ }^{1}$, ZHAO MingShui $^{2} \&$ FU ChengXin ${ }^{1 *}$ \\ ${ }^{1}$ Key Laboratory of Conservation Biology for Endangered Wildlife of the Ministry of Education, College of Life Sciences, Zhejiang University, \\ Hangzhou 310058, China; \\ ${ }^{2}$ Zhejiang Tianmushan National Nature Reserve Management Bureau, Linan 311311, China
}

Received March 18, 2011; accepted May 18, 2011

\begin{abstract}
An efficient procedure is outlined for rapid and mass propagation through in vitro culture of pseudobulbs collected in different seasons of an endangered orchid, Changnienia amoena Chien. Axillary buds formed on intact pseudobulbs (collected in April) after a 12-week incubation on half-strength Murashige and Skoog (1/2 MS) medium supplemented with $1 \mathrm{mg} \mathrm{L}^{-1} N^{6}$-benzyladenine (6-BA), $0.5 \mathrm{mg} \mathrm{L}^{-1} \alpha$-naphthaleneacetic acid (NAA), $100 \mathrm{ml} \mathrm{L}^{-1}$ coconut water and $0.8 \mathrm{~g} \mathrm{~L}^{-1}$ polyvinylpyrrolidone; no buds were observed on segmentalized pseudobulbs incubated on the same medium. The axillary buds obtained from pseudobulbs growing in the natural habitat in June were detached and incubated for 7 weeks on the same medium leading to 1.4 shoot buds per explant. With repeated subculturing of the shoots on $1 / 2 \mathrm{MS}$ medium supplemented with $2 \mathrm{mg} \mathrm{L}^{-1} 6-\mathrm{BA}$ and $0.5 \mathrm{mg} \mathrm{L}^{-1} \mathrm{NAA}_{\text {, a }}$ mean of 3.3 shoot buds per explant were observed on successive shoot cultures. A mean of 4.5 roots per shoot were induced on the optimal root induction medium with $1 / 2 \mathrm{MS}$ medium plus $1.0 \mathrm{mg} \mathrm{L}^{-1} \mathrm{NAA}$ and $0.1 \mathrm{mg} \mathrm{L}^{-1} 6$-BA and the highest rooting percentage was $88.9 \%$. Plantlets $4-5 \mathrm{~cm}$ in height were transplanted into pots containing a 1:1 humus and sand mixture and grown for 7 weeks in a greenhouse before being transferred to the field. The survival rate of these transplants was about $75 \%$ after two months of growth in the wild.
\end{abstract}

Changnienia amoena, pseudobulb, pseudobulb segment, axillary buds, in vitro propagation

Citation: Jiang W M, Zhao M S, Fu C X. Studies on in vitro regeneration competence of pseudobulb cultures in Changnienia amoena Chien. Chinese Sci Bull, 2011, 56: 2580-2585, doi: 10.1007/s11434-011-4596-7

Changnienia Chien is a monotypic genus in the tribe Calypsoeae of Orchidaceae [1]. The sole species, C. amoena Chien, is endemic to eastern and central China [2,3]. Its distribution is restricted to nutrient-rich, partially shaded and moist habitats in mixed deciduous/evergreen forests (Figure 1(a)) [4]. The adult plants are 10-18 cm in height and flower in April. The blossoms have an attractive light purple corolla with dark red spots on the lip, and its high ornamental value gives the plant horticultural importance (Figure 1(b),(c)). Most plants bear only one leaf, which lasts for about 8 months. For the rest of the year, the plant survives in the form of pseudobulbs [4], which are used as a medicine for treatment of sores and snakebites [2]. In recent

\footnotetext{
*Corresponding author (email: cxfu@zju.edu.cn)
}

years, populations have decreased acutely, and the current distribution is highly fragmented and discontinuous owing to the destruction and degradation of habitats by agriculture, silviculture, grazing and urbanization [2,4]. Consequently, $C$. amoena is categorized as a conservable species of second-grade in the China Plant Red Data Book [2] and is in greater danger of extinction. The fruit set of $C$. amoena is very low; under natural conditions, only $6 \%-12 \%$ of all individuals may set fruit [5]. As in other terrestrial orchids, seed germination of this species is also very difficult. Studies on seed germination of $C$. amoena conducted by the Shennongjia Research Station of the Chinese Academy of Sciences have quantified the low germination rate; the seeds did not germinate either in the natural habitat or on culture medium [6]. Instead, in its natural habitat, this plant typically 


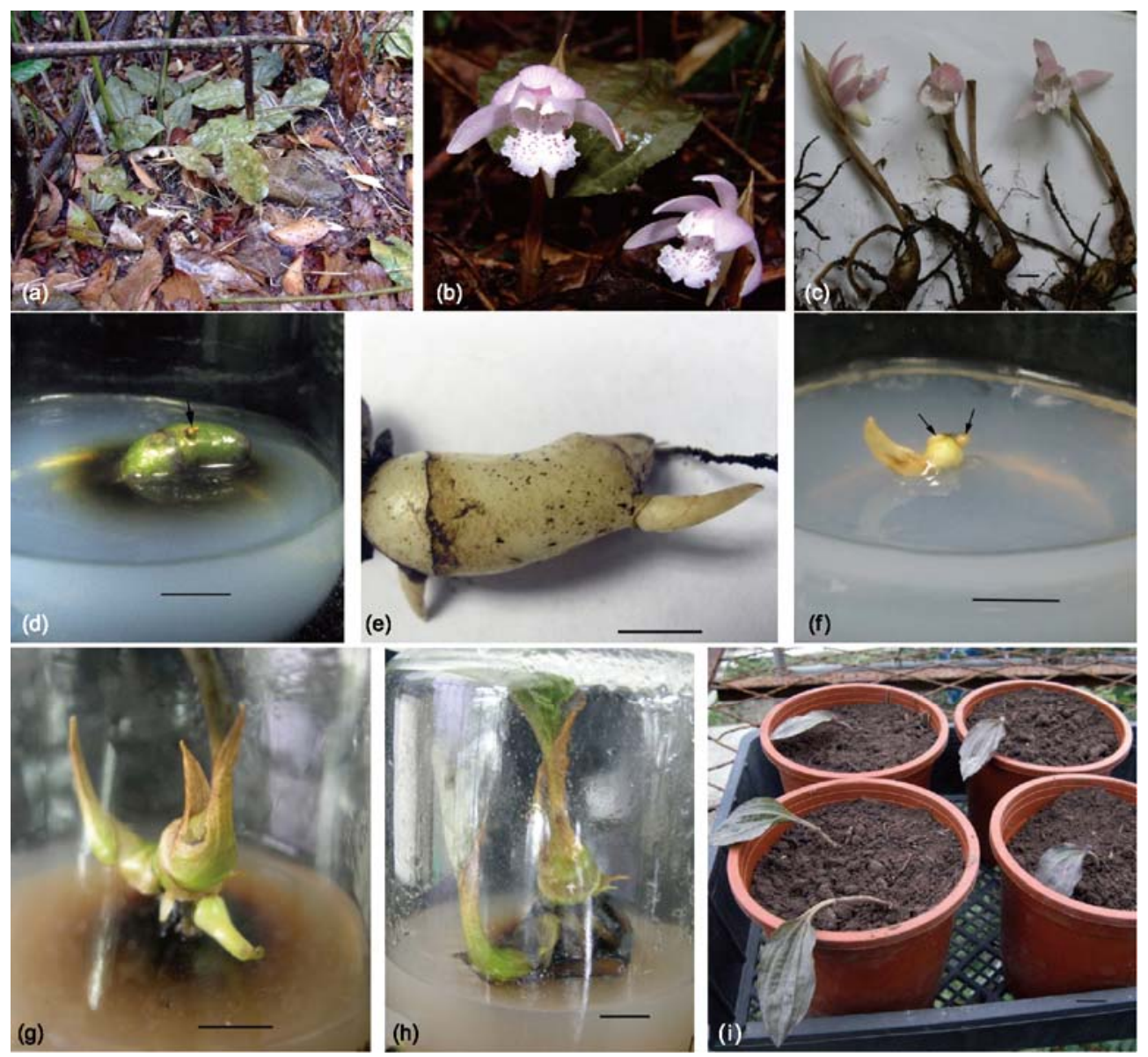

Figure 1 Shoot bud induction and plant regeneration from pseudobulbs in C. amoena. (a) C. amoena plants in their natural habitat; (b) C. amoena flowers; (c) plants collected in April, showing the plant gross morphology; (d) one whole pseudobulb collected in April and cultured for 12 weeks on 1/2 MS medium supplemented with $1 \mathrm{mg} \mathrm{L}^{-1} 6-\mathrm{BA}+0.5 \mathrm{mg} \mathrm{L}^{-1} \mathrm{NAA}$; arrow indicates a newly formed shoot bud; (e) pseudobulb collected in June with an axillary bud used as an explant; (f) an axillary bud cultured on initiation medium; the small, newly formed pseudobulb with 2 shoot primordia (indicated by arrows) developed after a 3-week culture; (g) shoots elongated after a 7-week culture; (h) well-rooted plantlets after culture on 1/2 MS medium supplemented with 1.0 mg $\mathrm{L}^{-1}$ NAA and $0.1 \mathrm{mg} \mathrm{L}^{-1} 6$-BA for 6 weeks; (i) acclimatization of plants in a greenhouse. Bar $=1 \mathrm{~cm}$.

multiplies by division of pseudobulbs in adult plants with two or more leaves. However, because the pseudobulb of individual with two leaves is very small, this method of propagation is also relatively inefficient and limited. As a result, it is necessary to develop an efficient regeneration procedure through pseudobulbs to accelerate the propagation of $C$. amoena in the interest of both horticulture and conservation.

Changnienia amoena has received less attention for in vitro propagation than other orchids in part because of its rareness and difficulty involved in collecting sufficient amounts of experimental material. To our knowledge, there is only one preliminary previous study on in vitro culture of C. amoena [7]. Detailed information on the optimal time for collecting pseudobulbs and the appropriate plant growth regulators used in shoot multiplication and rooting is necessary. In the present study, we investigated the effects of collecting time of pseudobulbs and the appropriate plant growth regulators on in vitro initiation of axillary buds, shoot multiplication and rooting of $C$. amoena, and suggest a standard procedure for in vitro propagation of this endangered species.

\section{Materials and methods}

\subsection{Plant materials and culture conditions}

Changnienia amoena plants were collected in flower from West Tianmu Mountain. Because populations of $C$. amoena are very sparse, only 17 plants were collected in April. Of these, 10 were planted in the Botanical Garden of Zhejiang University under natural conditions, and 7 were used as donor plants. The primary pseudobulbs (produced during the current year) were thoroughly washed with tap water and soaked in $75 \%(\mathrm{v} / \mathrm{v})$ ethanol for $30 \mathrm{~s}$, followed by one rinse in sterile distilled water. These materials were surface sterilized with $0.1 \%$ mercuric chloride for $15 \mathrm{~min}$ and then were subsequently rinsed in sterile distilled water 3 times. The 7 sterilized pseudobulbs were divided into 2 groups: 4 were directly placed intact onto the initiation medium, 1 per 
vessel, while the remaining three were cut horizontally from the centre into 2 equal halves, then further cut into pieces 5 $\mathrm{mm}$ in size. In each culture vessel, 4 segments were incubated on the initiation medium and a total of 6 vessels were used. The axillary buds collected in June were sterilized as above, but the duration of surface sterilization with $0.1 \%$ mercuric chloride was shortened to $8 \mathrm{~min}$, and the initiation medium was half-strength Murashige and Skoog (1/2 MS) basal medium [8] supplemented with $10 \mathrm{mg} \mathrm{L}^{-1}$ thiamine- $\mathrm{HCl}, 0.5 \mathrm{mg} \mathrm{L}^{-1}$ nicotinic acid, $0.5 \mathrm{mg} \mathrm{L}^{-1}$ pyridoxine$\mathrm{HCl}, 2 \mathrm{mg} \mathrm{L}^{-1}$ glycine, $100 \mathrm{mg} \mathrm{L}^{-1}$ myo- inositol, $1 \mathrm{mg} \mathrm{L}^{-1}$ $N^{6}$-benzyladenine (6-BA), $0.5 \mathrm{mg} \mathrm{L}^{-1} \alpha$-naphthalene acetic acid (NAA), $10 \%(\mathrm{v} / \mathrm{v})$ coconut water, $0.8 \%(\mathrm{w} / \mathrm{v})$ polyvinylpyrrolidone (PVP) and 3\% (w/v) sucrose. The $\mathrm{pH}$ of the medium was adjusted to 5.8 before gelling with $0.65 \%$ agar (Hepu, China). Each $40 \mathrm{~mL}$ of medium was dispensed into glass vessels $(7 \mathrm{~cm} \times 11 \mathrm{~cm})$ and autoclaved at $1.05 \mathrm{~kg} \mathrm{~cm}^{-2}$ $\left(121^{\circ} \mathrm{C}\right)$ for $20 \mathrm{~min}$. The cultures were maintained at $(25 \pm 2)^{\circ} \mathrm{C}$ under cool white fluorescent light with an irradiance of $36 \mu \mathrm{mol} \mathrm{m}^{-2} \mathrm{~s}^{-1}$ and 12/12 $\mathrm{h}$ (light/dark) photoperiod.

\subsection{Induction of shoots and multiplication}

The intact pseudobulbs or segments of pseudobulb were cultured for 12 weeks (subcultured at 4-week intervals); the axillary buds of pseudobulbs were maintained for 7 weeks to initiate the formation of shoots. The percentage of shoot formation and number of shoots per explant were evaluated. The shoots initiated from the pseudobulbs and the axillary buds were excised and transferred to the same medium for further propagation. With this step, a sufficient number of shoots was collected to study the effect of plant growth regulators on shoot proliferation. Half-strength MS medium containing different concentrations of 6-BA $(0,0.5,1,2$ or 4 $\left.\mathrm{mg} \mathrm{L}^{-1}\right)$ and NAA $\left(0.5 \mathrm{mg} \mathrm{L}^{-1}\right)$ were used for shoot multiplication. In each treatment, 6 shoots were cultured in 6 glass vessels. After the cultures were incubated for 7 weeks, the number of regenerated shoots and the shoot height were recorded.

\subsection{Rooting of shoots and acclimatization}

Shoots at about $3 \mathrm{~cm}$ height were excised and transferred to $1 / 2$ MS medium supplemented with NAA alone or in combination with 6-BA for rooting. Data were recorded after shoots were cultured for 6 weeks. Each value represents an average number of three replications with six explants each. The percentage of rooting and the average number of roots per shoot were evaluated. Well-rooted shoots were washed in water and transferred to plastic cups containing a sterilized mixture of humus and sand $(1: 1, \mathrm{v} / \mathrm{v})$, and were then covered with a plastic bag to maintain high humidity for 2 weeks followed by gradual exposure to sunlight. The plants were acclimatized for 7 weeks in a greenhouse, before being transferred to the field. Survival rate was assessed after 2 months.

\subsection{Statistical analysis}

A randomized complete block design was used for shoot multiplication and rooting. Three independent experiments and six cultures for each experiment were carried out. Data were subjected to analysis of variance, and means were compared using Duncan's multiple range test at the 0.05 level of significance [9].

\section{Results and discussion}

\subsection{Axillary bud induction from pseudobulbs}

As shown in Table 1, the competence of axillary buds forming from pseudobulb cultures depended on the developmental stage of the pseudobulb. When the pseudobulbs collected during the flowering season (April for every year) were cultured on the initiation medium for 4 weeks, they did not exhibit any axillary bud formation in either the intact pseudobulb or the pseudobulb segments. When these explants were subcultured on the same medium for 2-3 successive passages ( 4 weeks per passage), axillary buds formed from the intact pseudobulbs with 1-2 shoot buds per pseudobulb (Figure 1(d)). The pseudobulb segment subcultures, on the other hand, entirely failed to initiate axillary buds because the segment subcultures were necrotic.

When the pseudobulbs were collected in June, however, the axillary buds had already formed from pseudobulbs in the natural habitat (Figure 1(e)). Axillary buds were excised as inoculums, leading to new pseudobulb formation from the swelled basal site of the axillary bud after a 3-week culture. Furthermore, 2-3 new shoot primodia were initiated (Figure 1(f)) from the newly formed pseudobulb, resulting in the formation of 2-3 shoot buds after further culture for 4

Table 1 Shoot bud induction from C. amoena pseudobulbs collected in different seasons

\begin{tabular}{ccccc}
\hline Collection date & Treatment & No. of explants inoculated & ${\text { Shoot bud formation }(\%)^{\text {a) }}}$ & No. of shoot buds formed $^{\text {a) }}$ \\
\hline April & Intact pseudobulbs & 3 & 66.7 & 3 \\
& Pseudobulb segments & 3 & 0 & 0 \\
June & Axillary buds & 14 & 85.7 & 20 \\
\hline
\end{tabular}

a) The explants from pseudobulbs collected in April were cultured for 12 weeks (subcultured at 4-week intervals); the explants collected in June were cultured for 7 weeks. 
weeks (Figure $1(\mathrm{~g})$ ).

These results suggest that the suitable collecting time of pseudobulbs as explants is early June. While it is easier to find the plants when they are flowering in April, as in the present field survey, plants with pseudobulbs should be submerged in soil for further development until early June. The lack of axillary bud sprouts on the pseudobulb in April might be the result of nutrient consumption by the pseudobulb for flower formation. When the pseudobulbs were incubated on the initiation medium for 12 weeks, axillary buds were formed identical to the growth rhythm of pseudobulbs in the natural habitat.

The results also indicate that using intact pseudobulbs as explants is better than using segments of the pseudobulb. It was observed that large amounts of phenolic compounds were exuded from the cut surface of segments of the pseudobulb, likely leading to necrosis of the segmentalized pseudobulb. Similar responses have been reported in Bletilla ochracea [10] and Pleione hookeriana [11]. Our result differs from the observation in Tainia latifolia that formation of shoot buds occurred from pseudobulb-segment cultures [12].

Finally, this study also found that coconut water was also beneficial to the formation of shoot buds in $C$. amoena. Coconut water is a complex additive that contains many kinds of nutritional and hormonal substances [13]. It is commonly added to orchid medium to stimulate the formation of callus, protocorms or shoots in Cymbidium [14], Aranda [15], Dendrobium [16] and Vanda [17].

\subsection{Regeneration and mass multiplication}

The shoot buds (1-1.5 cm in height) formed on the initiation medium were subcultured on initiation medium for further propagation. After being subcultured for 2 passages (at 6-week intervals) on the initiation medium, 95 shoot buds from 20 axillary buds were collected from pseudobulbs in June. Of these, 90 buds were chosen and transferred to the regeneration medium for mass multiplication. Shoot buds cultured on 1/2 MS medium supplemented with $100 \mathrm{~mL} \mathrm{~L}^{-1}$ coconut water were induced with a mean of 1.3 shoots per explant (Table 2). Different concentrations of 6-BA in combination with $0.5 \mathrm{mg} \mathrm{L}^{-1} \mathrm{NAA}$ all facilitated the initiation and elongation of shoot buds. Combination of $2 \mathrm{mg} \mathrm{L}^{-1}$ 6-BA plus NAA most effectively multiplied shoot buds, with an efficiency of 3.3 shoots per explant (Table 2). After culture for 7 weeks in the absence of 6-BA and NAA, the average height of shoots was $2.1 \mathrm{~cm}$; however, in the presence of low concentrations of 6-BA $\left(0.5-1.0 \mathrm{mg} \mathrm{L}^{-1}\right)$ and $0.5 \mathrm{mg} \mathrm{L}^{-1} \mathrm{NAA}$, the shoot height increased to $4.0 \mathrm{~cm}$. With increasing 6-BA concentration to $4 \mathrm{mg} \mathrm{L}^{-1}$ plus $0.5 \mathrm{mg} \mathrm{L}^{-1}$ NAA, initiation and elongation of shoot buds were inhibited to some extent (Table 2). This result indicates that $2 \mathrm{mg} \mathrm{L}^{-1}$ 6-BA in combination with $0.5 \mathrm{mg} \mathrm{L}^{-1} \mathrm{NAA}$ was the most advantageous for shoot propagation. The proliferation
Table 2 Effect of different concentrations of 6-BA in combination with NAA on axillary bud propagation in C. amoena

\begin{tabular}{cccc}
\hline \multicolumn{2}{c}{ Plant growth regulators $\left(\mathrm{mg} \mathrm{L}^{-1}\right)$} & $\begin{array}{c}\text { No. of shoots per } \\
\text { explant }^{\mathrm{a})}\end{array}$ & $\begin{array}{c}\text { Shoot height } \\
(\mathrm{cm})^{\mathrm{a})}\end{array}$ \\
\cline { 1 - 3 } 6-BA & NAA & $1.3 \pm 0.1 \mathrm{c}$ & $2.1 \pm 0.1 \mathrm{~b}$ \\
0 & 0 & $2.1 \pm 0.1 \mathrm{~b}$ & $4.1 \pm 0.2 \mathrm{a}$ \\
1 & 0.5 & $2.5 \pm 0.1 \mathrm{~b}$ & $4.0 \pm 0.1 \mathrm{a}$ \\
2 & 0.5 & $3.3 \pm 0.1 \mathrm{a}$ & $3.8 \pm 0.1 \mathrm{a}$ \\
4 & 0.5 & $2.5 \pm 0.2 \mathrm{~b}$ & $2.3 \pm 0.2 \mathrm{~b}$
\end{tabular}

a) Values represent the mean \pm SE. Values within a column followed by the same letter are not significantly different at the 0.05 level of significance with Duncan's multiple range test. The data were recorded after 7 weeks of culture.

manipulation can be repeated every 7 weeks and the proliferation rate will reach 4 . However, it was previously reported [7] that the proliferation rate reached as high as 10 on MS medium supplemented with $2.0 \mathrm{mg} \mathrm{L}^{-1}$ 6-BA, 0.1 $\mathrm{mg} \mathrm{L} \mathrm{L}^{-1} \mathrm{NAA}$ and $100 \mathrm{~g} \mathrm{~L}^{-1}$ banana homogenate in $C$. amoena when the shoots from the initiation medium were subcultured. In this study, we did not observe such a high proliferation rate. The high rate observed by the previous study might be a result of the ratio of 6-BA: NAA and/or supplementation with banana homogenate. Paek and Kozai [18] reported 6-BA to be the best cytokinin for inducing shoot formation, for switching rhizome tissues into protocorm-like bodies (PLBs) and for direct formation of multiple shoots from branched rhizomes in most species of Cymbidium. Auxins (especially NAA) in combination with 6-BA are known to stimulate shoot initiation and proliferation from rhizome segments in Cymbidium kanran [19] and from pseudobulbs in T. latifolia [12], B. striata [20], $P$. hookeriana [11], P. bulbocodioides [21] and Cremastra appendiculata [22]. These results are similar to those of the present study on C. amoena.

In vitro regeneration in orchids might occur via direct shoot bud formation or through the mediation of PLBs. Some epiphytic species such as Lycaste [23] can form PLBs using field-grown axillary buds as explants. Most of the terrestrial species such as Geodorum densiflorum [24,25], $C$. forrestii [26], P. bulbocodioides [21] and C. appendiculata [22] can form shoots from rhizome segments or pseudobulbs. In the present study, in $C$. amoena only the shoot buds derived from pseudobulbs can be induced by in vitro propagation. Although the multiplication rate is still low, compared with the dividing pseudobulbs propagation in the natural habitat, this method might rapidly provide a large number of plantlets in a short period. Of course, more effective propagation techniques might exist, and the subject deserves further study.

\subsection{Rooting and transplantation}

The regenerated shoots about $3 \mathrm{~cm}$ in height were transferred to $1 / 2 \mathrm{MS}$ medium alone or supplemented with NAA 
alone or in combination with $0.1 \mathrm{mg} \mathrm{L}^{-1}$ 6-BA. When the shoots were grown on $1 / 2 \mathrm{MS}$ medium without exogenous phytohormones, a mere $22.2 \%$ of shoots produced roots. The addition of NAA to the medium enhanced the root induction, and the percentage of rooting increased with increasing concentrations of NAA. The combination of 0.1 $\mathrm{mg} \mathrm{L}^{-1} 6-\mathrm{BA}$ and NAA had a synergistic effect on rooting. The most effective combination was $1.0 \mathrm{mg} \mathrm{L}^{-1} \mathrm{NAA}$ and $0.1 \mathrm{mg} \mathrm{L}^{-1}$ 6-BA, with $88.9 \%$ of the shoots forming roots (Table 3, Figure 1(h)). After culture for 6 weeks on this medium, the efficiency of rooting was an average of 4.5 roots per shoot. The positive effect of rooting by NAA plus 6-BA in the present study agrees with similar findings in other terrestrial orchid species, such as B. striata [20,27].

After culture for 6 weeks, the plantlets reached $4-5 \mathrm{~cm}$ in height with 3 or 4 roots per shoot and the diameter of pseudobulb was $0.7-1 \mathrm{~cm}$. Because $C$. amoena is a winter-green orchid, it is better to acclimatize the plantlets in autumn. The culture vessels were moved to a greenhouse for two weeks. The plantlets were removed gently from the culture vessels, washed, transferred to plastic pots containing humus and sand (1:1), and maintained at high humidity by covering them with a transparent bag for 2 weeks. This was followed by a gradual exposure to sunlight. After acclimatization for 7 weeks, plants were transferred to field conditions, under which the survival percentage was $75 \%$ after 2 months.

When the plants that were well-rooted and with an expanded leaf were cultured in the medium for more than 3 months, it was found that the leaf turned yellow and the roots blackened or died, leaving only the pseudobulbs. This phenomenon was similar to dormant pseudobulbs of $C$. amoena growing in natural conditions. Similar results were observed in previous studies on P. yunnanensis [28] and $P$. albiflora [29].

Orchid plants are naturally rich in phenolic compounds, which may seep into the medium, cause the medium to become brown, and restrict growth of the explants. Antioxidants are often incorporated in the culture medium to eliminate the inhibitory phenolics released by tissues in culture. In the present study, PVP, an effective antioxidant that prevents phenolic oxidation by adsorption through hydrogen

Table 3 Effect of different concentrations of NAA alone or in combination with 6-BA on root induction from shoots in $C$. amoena

\begin{tabular}{cccc}
\hline \multicolumn{2}{c}{ Plant growth regulators $\left(\mathrm{mg} \mathrm{L}^{-1}\right)$} & $\begin{array}{c}\text { Percentage of } \\
\text { shoots rooted }(\%)^{\mathrm{a})}\end{array}$ & $\begin{array}{c}\text { No. of roots } \\
\text { per shoot }^{\mathrm{a})}\end{array}$ \\
\hline 0 & 6-BA & $22.2 \pm 5.5 \mathrm{~d}$ & $1.8 \pm 0.2 \mathrm{c}$ \\
0.5 & 0 & $44.4 \pm 5.6 \mathrm{c}$ & $2.8 \pm 0.6 \mathrm{~b}$ \\
1 & & $66.7 \pm 9.6 \mathrm{~b}$ & $3.7 \pm 0.3 \mathrm{a}$ \\
0.5 & 0.1 & $72.2 \pm 5.5 \mathrm{ab}$ & $4.3 \pm 0.4 \mathrm{a}$ \\
1 & 0.1 & $88.9 \pm 5.6 \mathrm{a}$ & $4.5 \pm 0.6 \mathrm{a}$ \\
\hline
\end{tabular}

a) Values represent the mean \pm SE. Values within a column followed by the same letter are not significantly different at the 0.05 level of significance with Duncan's multiple range test. The data were recorded after 6 weeks of culture. bonding [30], was unsuccessful in preventing tissue blackening in $C$. amoena. Further experiments should be performed to evaluate other antioxidants such as activated charcoal, citric acid and ascorbic acid for prevention of tissue blackening in C. amoena.

\section{Conclusion}

This simple and efficient method for micropropagation of plantlets via the culture of axillary buds from pseudobulbs could be used for large-scale propagation and ex situ conservation of the endangered and ornamental terrestrial orchid C. amoena.

The authors thank Zeng-Lin Cheng for help during fieldwork. This work was supported by Zhejiang Provincial Natural Science Foundation (Y507195) and the National Key Project of Scientific and Technical Supporting Programs Funded by Ministry of Science \& Technology of China (2008BAC39B05).

1 Dressler R L. Phylogeny and classification of the orchid family. Cambridge: Cambridge University Press, 1993

2 Fu L G. China Plant Red Data Book: Rare and Endangered Plants I. Beijing: Science Press, 1992

3 Chen S C, Tsi Z H, Lang K Y, et al. Flora of China (18). Beijing: Science Press, 1999

4 Xiong G M, Xie Z Q, Xiong X G, et al. The phenology, reproduction and community characteristics of Changnienia amoena, a rare orchid, in southern part of Shennongjia range (in Chinese). Acta Ecol Sin, 2003, 23: 173-179

5 Sun H Q, Luo Y B, Alexandersson R, et al. Pollination biology of the deceptive orchid Changnienia amoena. Bot J Linn Soc, 2006, 150: $165-175$

6 Xie Z Q, Wu J Q, Xiong G M. Conservation Ecology of Rare and Endangered Plants in the Three Gorges Reservoir Area. Beijing: China Water Power Press, 2006

7 Gao L, Yang B, Li H L. Tissue culture and rapid propagation of Changnienia amoena (in Chinese). Subtro Plant Sci, 2010, 39: 79

8 Murashige T, Skoog F. A revised medium for rapid growth and bioassays with tobacco tissue culture. Physiol Plant, 1962, 15: 473-497

9 Duncan D B. Multiple range and multiple F test. Biometrics, 1955, 11: $1-42$

10 Zhu Y Q, Wang X G. Tissue culture and rapid propagation technique for Bletilla ochracea (in Chinese). J Zhejiang For Coll, 1999, 16: 164-169

11 Yu X J, Na H Y, Hu X L, et al. Study on tissue culture of Pleione hookeriana (in Chinese). J Sichuan Univ (Nat Sci Ed), 2007, 44: 891-894

12 Sungkumlong, Deb C R. Regeneration competence of Tainia latifolia (Lindl.) Benth ex Hook pseudobulb segments: An in vitro study. Indian J Biotech, 2009, 8: 121-126

13 Dix L, Van S J. Auxin and gibberellins-like substances in coconut milk and malt extract. Plant Cell Tissue Org Cult, 1982, 1: 239-245

14 Vyas S, Guha S, Kapoor P, et al. Micropropagation of Cymbidium Sleeping Nymph through protocorm-like bodies production by thin cell layer culture. Sci Hortic, 2010, 123: 551-557

15 Goh C J, Wong P F. Micropropagation of the monopodial orchid hybrid Aranda Deborah using inflorescence explants. Sci Hortic, 1990, 44: 315-321

16 Roy J, Banerjee N. Induction of callus and plant regeneration from shoot-tip explants of Dendrobium fimbriatum Lindl. Var. oculatum H.K.f. Sci Hortic, 2003, 97: 333-340 
17 Seeni S, Latha P G. In vitro multiplication and eco-rehabilitation of the endangered Blue Vanda. Plant Cell Tissue Org Cult, 2000, 61: $1-8$

18 Paek KY, Kozai T. Micropropagation of temperate Cymbidium via rhizome culture. Horttechnology, 1998, 8: 175-180

19 Shimasaki K, Uemoto S. Micropropagation of a terrestrial Cymbidium species using rhizomes developed from seeds and pseudobulbs. Plant Cell Tissue Org Cult, 1990, 22: 237-244

20 Shi Y P, Li F, Ling Z Z. Tissue culture and rapid propagation technique for Bletilla striata (in Chinese). Guangxi Agric Sci, 2009, 40: 1408-1410

$21 \mathrm{Li} \mathrm{H} \mathrm{L,} \mathrm{Fu} \mathrm{Z} \mathrm{H,} \mathrm{Yang} \mathrm{B.} \mathrm{Tissue} \mathrm{culture} \mathrm{of} \mathrm{Pleione} \mathrm{bulbocodioides}$ (Franch. ) Rolfe (in Chinese). Plant Physiol Comm, 2005, 41: 632

22 Mao T F, Ding Y. Tissue culture and plantlet regeneration of Cremastra appendiculata (in Chinese). Plant Physiol Comm, 2004, 40: 716

23 Huang C H, Chung J P. Efficient indirect induction of protocorm-like bodies and shoot proliferation using field-grown axillary buds of a Lycaste hybrid. Plant Cell Tissue Org Cult, 2010, doi: 10.1007/ s11240-010-9890-6
24 Sheelavantmath S S, Murthy $\mathrm{H} \mathrm{N}$, Pyati A N, et al. In vitro propagation of the endangered orchid, Geodorum densiflorum (Lam.) Schltr. through rhizome section culture. Plant Cell Tissue Org Cult, 2000, 60: $151-154$

25 Roy J, Banerjee N. Rhizome and shoot development during in vitro propagation of Geodorum densiflorum (Lam.). Schltr. Sci Hortic, 2002, 94: 181-192

26 Paek K Y, Yeung E C. The effect of 1-naphthalene acetic acid and $\mathrm{N}^{6}$-benzyladenine on the growth of Cymbidium forrestii rhizomes in vitro. Plant Cell Tissue Org Cult, 1991, 24: 65-71

27 Vij S P, Dhiman A. Regenerative competence of Bletilla striata pseudobulb segments: A study in vitro. J Orchid Soc India, 1997, 11: 93

28 Huang J L, Hu H, Li S Y. In vitro germination of Pleione yunnanensis (in Chinese). Acta Hortic Sin, 2005, 2: 313

29 Chen Z L, Ye X L, Liang C Y, et al. Tissue culture and rapid propogation of Pleione albiflora (in Chinese). Plant Physiol Comm, 2004, 40: 455

30 Gerge E F, Sherrington P D. Plant Propagation by Tissue Culture. England: Exegetics Ltd Basingstoke, 1984

Open Access This article is distributed under the terms of the Creative Commons Attribution License which permits any use, distribution, and reproduction in any medium, provided the original author(s) and source are credited. 